\title{
The Development of the Archegonium and Fertilization in the Hemlock Spruce (Tsuga canadensis, Carr.).
}

\author{
BY
}

WILLIAM A. MURRILL ${ }^{1}$.

With Plates XXXI and XXXII.

THE material for these studies has been collected with 1 great regularity for the past three years from a hemlock standing alone on the bank of a stream in an open pasture near the University grounds. The tree is well advanced in years and has fruited heavily every season. The female cones are terminal on the larger horizontal twigs, the male cones occurring in great abundance on the smaller ones. At pollination, there is no change in the position of the female cones; they remain slightly pendent, the scales opening a little and receiving the pollen from below as it floats upward. Soon after pollination, the pedicels lengthen and the cones, which are now considerably heavier, hang directly downward. Pollination on a single tree occupies about three days, but a week or more elapses before it is completed on all the trees of this locality. In 1899 it was at its maximum on May I9, in I900 on May 22. The seasons frequently differ more than this.

${ }_{1}$ Read before the Botanical Society of America, at its sixth Annual Meeting in New York City, June 28, 1900.

[Annals of Botany, Vol. XIV. No, LVI, December, I900.] 


\section{Murrill.-The Development of the Archegonium}

Two weeks after pollination the archegonial rudiments appear; a week later the necks are formed; and two weeks after this the ventral canal-cell is cut off. Fertilization takes place five days after the ventral canal-cell is formed. It varies for the same and different trees much as pollination does, so that stages of fertilization may be obtained for a week or longer. After one season's experience, it is possible to determine with tolerable accuracy the date of fertilization, but, after all, there is an element of chance that can be eliminated only by regular and abundant collections. I put up material from one to three times a day. The hour of collection seems to be of little consequence. The central cell was found in active division in cones collected at 10 a.m. in bright sunlight, in others collected at 7 p.m., and in still others on branches taken from the tree at 7 p.m., and kept in water until I I p.m. Fertilization stages were abundant in cones collected at 9 a.m. and at 9 p.m. of the same day.

\section{Methods.}

The material was placed in the fixing solution within a few minutes after it was taken from the tree. Only the middle portion of the cone was used, as this part contains the bestdeveloped ovules. In the younger stages, the terminal sterile portion of the scale was cut away, leaving the two ovules attached side by side; in older stages, the ovules were entirely separated from the scale, and, as the coats became hardened, they were cut away at the sides, exposing the endosperm directly to the fixing fluid. The endosperm should be quite well filled out before this is done, otherwise it may collapse. After the embryos are well established, it is well to remove the coats entirely. Many approved fixing methods have been tried, with variations in strength, time, and temperature, but for these studies none has been found equal to Mottier's modification of Flemming's solution, used fresh and allowed to act for twenty-four hours at about $30^{\circ} \mathrm{C}$. During the preparation and fixing of the ovules the bottles were repeatedly shaken to ensure equal contact of fresh 
solution on all sides. The solution was sometimes changed at the end of one or two hours. Into each bottle was placed at the time of fixing a small rectangular piece of linen paper bearing in pencil the current number. This paper remained with the material through all of the succeeding changes, appearing finally at the bottom of the paraffin block as a permanent and very convenient label. After fixing, the material was washed for twelve to twenty-four hours in running water, dehydrated in grades of alcohol, bleached with a seventy per cent. alcoholic solution of hydrogen peroxide, and the dehydration completed in commercial and absolute alcohol several times changed. It was then brought very gradually into cedar oil, and transferred with equal care into paraffin melting at $54^{\circ}$, in which it was imbedded. I have found it expedient to store material in seventy or eighty per cent. alcohol for a short time after bleaching, and to allow a number of bottles to accumulate before proceeding farther with the imbedding. Time and chemicals are thus saved and more attention is given to the details of the process.

A Minot-Zimmermann revolving microtome was used in cutting the sections. In cases where the material was poor in stages, a number of ovules were imbedded in rectangular groups and sectioned together. Archegonia were thus examined by thousands instead of by hundreds. Sections were cut $6.6 \mu$ and $13.3 \mu$ in thickness. The ribbons were floated out on water, fixed to the slide with Mayer's albumen fixative, dried thoroughly, and melted down by placing the slides in the paraffin bath for an hour or two. The slides were numbered with figures and letters according to the system devised by Marks. A mixture of vermilion and sodium silicate in a little water supplied a convenient and indelible medium. Preliminary to staining, the slides were passed through xylol, alcohol, hydrogen peroxide solution and water. Several staining combinations were used, the well-known Safranin-Gentian-Violet-Orange G. combination proving the best; though Iron-Hematoxylin alone and combined with acid Fuchsin, and Delafield's Hematoxylin 


\section{Murrill.-The Development of the Archegonium}

alone and followed by Orange G. or Bismarck-Brown, were useful for comparison in some stages of archegonial development and oögenesis. Methyl-Green, Fuchsin, and Orange G. were used in the search for centrospheres and some slides were covered without staining. After the usual process of dehydration with absolute alcohol and clearing with oil of cloves, the sections were treated for several minutes with Bergamot oil before being covered with balsam. This removes foreign particles and ensures the permanence of certain stains that are extracted by the oil of cloves: it also flows easily and dries quickly.

The ORigin AND Development of the ARChegonia Before the Formation of the Ventral Canal-Cell.

The archegonia of Tsuga arise, as they do in other Gymnosperms, from superficial cells at the apex of the prothallium which cease to divide and become conspicuous for their large size and the abundance of protoplasm which they contain. Fig. I, Plate XXXI, shows one of these archegonial rudiments with its large nucleus and its radiating bands of protoplasm, which, in a later stage (Fig. 2) are confined chiefly to the upper portion of the cell, while the lower tapering portion is comparatively empty. Between these rudiments are other cells which continue to divide (Fig. 3) and later give rise to the archegonial sheath (Fig. 4). About one week after the differentiation of the archegonial rudiment, the neck-cell is cut off (Figs. 2-3). It at first has the form of a circular disk surmounting the central cell and equalling it in breadth but not in height. As the central cell grows, it appears comparatively narrow and more elongated and also shows considerable variation. In the greater number of well-developed archegonia, it divides into two cells about the time when the ventral canal-cell is formed (Figs. 4-6). The division-wall may be transverse, oblique, or longitudinal, but it is most often oblique. In many cases the neck-cell remains undivided, and, on the other hand, one 
frequently finds three or four cells in the neck of a mature archegonium (Figs. 8-10). Differences of opinion concerning the number of neck-cells in the archegonia of Tsuga are probably due to the fact that the division often occurs late. After examining a large number, I must agree with Hofmeister that two cells are more frequently present than any other number. Had Mottier (1892) examined more of the mature archegonia, he would have probably found two cells even more frequent than he supposed.

Returning to the condition of the central cell after the neck-cell was cut off, it will be remembered that it tapers towards its lower extremity and is almost entirely free from protoplasmic contents. Though its nucleus remains at the apex just beneath the neck, rapid changes take place in the form and contents of the cell. It increases greatly in size, and a delicate reticulum appears with numerous vacuoles in its meshes containing cell-sap (Fig. I1). Enveloping the central cell is a sheath of cells rich in protoplasm which furnish the central cell with food, the endosperm still growing vigorously and crowding back the disorganized nucellar tissue. In place of the delicate network shown in Fig. I1, the central cell soon shows spherical vacuoles filled with granule; and other food-masses (Fig. I2). These appear first at the periphery near the food-cells and later come to occupy the whole cavity, with the exception of one or two large vacuoles at the centre. A transverse section of a prothallium with five archegonia at this stage is shown in Fig. I6.

I cannot confirm for Tsuga the results of Arnoldi's recent studies (I900) on the proteid vacuoles of the Abietineae. It may be that further search on my part will reveal the passage of the nuclei of the sheath-cells into the central cells, but very careful examination of numerous archegonia in all stages of development has thus far failed to show a single undoubted example of such passage. I find the nuclei of the sheath-cells staining diffusely at times, as described by Ikeno $(1898)$ for Cycas, and I observe collections of granules in the outer vacuoles of the central cells which very much resemble 
the sheath-nuclei, but the sheath-cells are never found without their nuclei. The sheath remains one-layered, though its cells often divide as the archegonium grows. At points where the archegonia come into close contact (Fig. I6), the sheath is frequently crushed and destroyed, but throughout most of its extent the cells and their nuclei continue active during the life of the archegonium.

\section{The Formation of the Ventral Canal-Cell.}

Shortly before the division of the central cell, an accumulation of cytoplasm may be observed beneath the nucleus a little to one side of the longitudinal axis of the archegonium (Fig. I3). This accumulation is a dense mass of fibres with small granules of uniform size scattered through it, the whole being continuous with the cytoplasm around it and taking the same brownish stain with the Flemming combination. From the first it is closely pressed against the nuclear membrane, and soon begins to push it inward in the form of blunt, unequal projections (Fig. I7). This fibrous mass continues to increase in size and to send out radiations far into the cytoplasm, thus forming a support for the free lower pole. These radiations grow at their free ends from the cyto-reticulum and extend in all directions, but are of necessity short on the side next the nucleus.

The spindle-fibres arise within this mass and grow upward against and press in the nuclear membrane, while they also draw to a point below and establish the lower pole of the spindle (Figs. I8-2I). At the pole there is usually greater density and frequently a rounded granule (Fig. 24), but nothing could be discovered corresponding to a centrosome, even with the most favourable methods. Activity at the upper pole begins late and is always feeble. The cytoplasm between the nucleus and the neck-cell is all of a density intermediate between that of the ordinary cytoplasm and that collected at the lower pole. In a few cases a minute hyaline lenticular area was observed at the upper pole, resembling the collections of sap usually seen between the polar caps of 
dividing vegetative nuclei and the nuclear membrane (Fig. 15). In later preparations this area seemed to have broadened and filled with delicate threads (Fig. I8) which later drew together above, but I cannot be sure of this ${ }^{1}$. Possibly the collection of sap is so small that it often disappears in fixing. Careful search was made for a similar collection at the lower pole, but without success.

The further development of the spindle is very rapid. The nuclear membrane disappears below and the spindle-fibres press into the nuclear cavity and connect with the linen network, already partially arranged in such a way as to continue the fibres to the chromosomes or through the centre of the cavity. The fibres soon become homogeneous below, while at their upper extremities they are still only rows of granules (Fig. 2I). Nothing now remains in the nuclear cavity except the spindlethreads and the homogeneous chromatin segments. The large spreading bundle of fibres originating from below traverses about two-thirds of the nuclear cavity before connecting with those from the upper pole. The nucleus consequently becomes pear-shaped at this stage, with the upper end larger. As the spindle-fibres draw in towards the centre, the chromosomes are forced from their peripheral position and come to lie along the central part of the spindle (Fig. 23). At the same time the upper pole is somewhat elevated and appears as an abrupt but sharp point rising out of the nuclear cavity. Supporting fibres run from this pole to the cell-wall and in various directions through the neighbouring cytoplasm (Fig. 25).

In the plate-stage (Fig. 26), the chromosomes show the form and arrangement characteristic of that class of divisions recently denominated 'typical' by Strasburger (1900), and

${ }^{1}$ It is often impossible to demonstrate the existence of an extra-nuclear spindlerudiment at the upper pole, but the fibres appear to collect in bundles within the membrane and to unite at one point when the polarity becomes more pronounced. The narrowing and consequent stretching of the spindle as the metaphase is approached would elevate the upper pole and give it the appearance of penetrating the membrane (Fig. 22). In Larix Americana there is still less cytoplasm above the nucleus than in Tsuga, which makes the difference in the two poles yet more marked. 
are drawn to the poles as attenuated U's or V's (Fig. 27). The cell-plate is laid down from the centre outwards. It begins in the dispirem stage and keeps pace for some time with the growing daughter-nuclei (Figs. 29, 30). The fibres thicken at the centre, and the thickened portions fuse together at the side. The spindle then broadens out and stretches the young cell-plate until it connects with the wall of the mothercell (Fig. 31). The original nuclear membrane does not entirely disappear until the daughter-nuclei are formed. It then splits up into slender fibres and fades away into the surrounding cytoplasm.

The division above described, while it resembles that described by Rosen (I895), Hof (I898), Nemec (I 899), and others for the vegetative cells of various plants, in the extranuclear origin of the spindle and the details of its construction, nevertheless differs very strikingly from that type by reason of the fact that the spindle is at first asymmetrical and originates in a large fibrous mass beneath the nucleus, which appears early, grows to an immense size, and remains for some time after the division is completed, being enveloped during its existence by numerous fibres radiating from it far into the surrounding cytoplasm.

Various authors (Ikeno, I898, p. 567 ; Blackman, 1898 ; Chamberlain, I899, figs. I, 2 ; and others) have described or figured the nucleus of the central cell as remaining at the cell-apex until division occurs, and it would be interesting to know whether more careful study would show such a method of spindle-formation as I have discovered in Tsuga in these or similar cases of unequal division.

This collection of cytoplasm is probably due to the need of a support for the free lower pole, and the numerous radiations from it doubtless add greatly to its stability. The origin and growth of the spindle chiefly on the lower side of the nucleus seem to indicate that the force controlling division is largely centred there. 


\section{Further Changes in the EgG and the Ventral} CANAL-CELl before the ENTRANCE OF THE

\section{SPERM-CELLS.}

When the nuclear membrane is deposited about the young egg-nucleus, the chromatin is in the form of a thick homogeneous band which is gradually drawn out until the chromatin granules appear distinct on the linin threads. At the same time the threads anastomose to form an ordinary cell-reticulum, in which several small nucleoli appear (Figs. 29-31). The nucleus increases rapidly in size and begins to move down toward the centre of the egg. The chromatin now occupies chiefly the upper half, the lower part being comparatively empty (Fig. 32). As it begins to move, it usually becomes elliptical in form (Fig. 33), and remains so until fertilized, but if the archegonium is very broad it may remain perfectly spherical. As it increases in size, it takes in considerable food-material and the network becomes coarser and the nucleoli larger. When the centre of the egg is reached, it remains stationary in the resting condition until fertilized. The granules in the cytoplasm of the egg are arranged in rows radiating from the nuclear membrane. This arrangement appears with the formation of the egg and disappears with fertilization.

The nucleoli of the egg-nucleus first appear as minute spheres hardly distinguishable from collections of chromatin. They increase rapidly in size, however, and apparently unite to form larger ones and often a single one of immense size (Fig. 35). When first formed, these larger ones are very plastic and easily take the sickle-form under the influence of fixing agents. Later, the outer shell becomes firm and dense and takes a deep purple stain with Gentian-Violet, while the vesicular mass within stains feebly with Orange, and shows a delicate reticulum probably consisting of dissolved proteid substance precipitated by chromic acid. The shell is frequently found broken in mounted preparations, and the nucleolus then 
suggests a sperm-nucleus with its membrane breaking away, and the contents dissolving in the nuclear substance of the egg.

The large vacuole at the centre of the egg changes its position as the nucleus moves down, and, passing it on one side (Fig. 34), comes to lie near the apex of the cell. The vacuole is apparently somewhat diminished in size as the egg-nucleus increases, and it is not improbable that some of the cell-sap from the vacuole passes into the nucleus while they lie near together. The concentration of cytoplasm and food materials near the centre, in consequence of the change in position of the nucleus, leaves more room for the vacuole near the apical portion of the egg. Another vacuole with contents very similar to those of the nucleus is regularly observed $^{1}$ in the mature egg situated just beneath the ventral canal-cell (Fig. 10). It is quite different from the proteidvacuoles in appearance, but seems to originate in one or more of the latter upon the relief of pressure in the apical region by the enlargement of their enclosing membranes and the expansion and distribution of their contents. This 'nuclear' vacuole sometimes fuses with the 'empty' vacuole as it approaches the apex, but the latter more often remains to one side and a little below the former. Near these two vacuoles is the receptive spot of the egg.

The ventral canal-cell is fairly persistent in Tsuga. When division is completed its nucleus is equal in size and similar in structure to the nucleus of the egg, and for some time shows the same stages of development. But when the nucleus has nearly filled the ventral canal-cell its membrane becomes wavy in outline, the scanty reticulum occupies only a small portion of the nuclear cavity, and the nucleoli remain minute and scattered. Growth having ceased, signs of disorganization soon appear. The nuclear contents become amorphous and stain diffusely, while the nucleus and the cell become more

\footnotetext{
1 An archegonium rendered very abnormal by developing far down on the side
} of the prothallium showed this nuclear vacuole in all respects normal. 
irregular and misshapen in outline. It is at this stage that the pollen-tube usually enters the neck of the archegonium.

\section{The Entrance of the Contents of the Pollen-}

\section{TUBE INTO THE EGG.}

The pollen-tube reaches the egg by penetrating the neck of the archegonium, the contents of the neck-cells being pressed to one side or swept away entirely. They are frequently found crowded down near the apex of the egg with the remains of the ventral canal-cell (Fig. 36). On reaching the egg the tube spreads out over it and causes its apex to stain diffusely. Further than this the tube itself does not go, but the contents of its terminal portion are emptied into the egg near the empty vacuole, the membrane of the egg usually closing up again, but sometimes remaining open at the point of entrance.

The contents of the pollen-tube thus cast into the egg consist of two sperm-cells, the stalk-cell, the vegetative nucleus, and some protoplasm and starch from the tube-cavity (Fig. 36). The stalk-cell nucleus is small, perfectly spherical, and conspicuous by reason of its thick, deeply-stained reticulum (Fig. 39). The cytoplasm accompanying it is scanty, vacuolate, and irregular in outline. The vegetative nucleus is larger, ovoid or irregular in outline, and unaccompanied by cytoplasm. It contains a delicate network with granules and nucleoli, and takes a pale, slightly diffuse stain with Gentian-Violet.

Above these smaller nuclei lie the ellipsoidal sperm-cells, each with dense cytoplasmic contents and a large nucleus. The sperm-nuclei differ considerably in size and appearance. The one that was in advance in the pollen-tube, which I shall call the first sperm-nucleus, is about twice the diameter of its companion, and its contents are so dense that its two small purplestaining nucleoli are almost hidden from view. The second sperm-nucleus is less dense and shows two large and prominent nucleoli that stain a clear red with safranin. It tends to conform more to the shape of its cell, and also corresponds more nearly to the resting stage than does the larger nucleus. 


\section{Murrill.-The Development of the Archegonium}

It is through the first sperm-nucleus that fertilization is accomplished. A short time after its entrance into the egg it slips from its cell and moves with accelerated velocity towards the egg-nucleus, the latter remaining stationary and inactive, but probably exercising chemotactic attraction on the sperm-nucleus by reason of its rich proteid contents. There is no depression at the apex of the egg-nucleus, nor other evidence in it of the approach of the sperm. The conjugation-path is a straight line from near the point of entrance. Since this point is ordinarily at the side near the top of the egg, the sperm-nucleus usually strikes the eggnucleus slightly to one side of its apex; when entrance into the egg is effected at the apex, the sperm-nucleus strikes the egg-nucleus directly at its apex (Fig. $3^{8}$ ). Conjugation occasionally occurs at the middle of one side of the eggnucleus, as shown in Fig. 40. The same figure also shows the second sperm-nucleus very near the egg-nucleus, but there is nothing in this or other preparations of mine to indicate that both sperm-nuclei ever unite with the nucleus of the egg.

In Conifers, the sperm-cell is very similar to a pure vegetative cell. In the Pteridophytes, the nucleus is condensed and elongated, with reduced cytoplasm and active cilia. In Phanerogams, the nuclei may be elongated, but cytoplasm and cilia are absent. The sperm-cells of Ginkgo and the Cycads differ from those of the Conifers in possessing a cilia-bearing band which propels the cells from the tip of the pollen-tube to the apex of the egg. In the Conifers, the pollen-tube penetrates to the egg and the cilia-bearing band is unnecessary and absent.

After the first sperm-nucleus has moved to the egg-nucleus the second sperm-nucleus remains for a long time in its cytoplasm in the upper part of the egg (Fig. $3^{8}$ ), and is then gradually absorbed, usually after the other contents of the pollen-tube have disappeared. The discovery of a tripolar spindle (Fig. 46) in the position commonly occupied by the second sperm-nucleus at first led me to believe that, being 
fed by the egg-cytoplasm, this nucleus had entered upon mitotic division, just as the functional sperm-nucleus presumably initiates the division which, with the assistance of the egg-nucleus, results in the first segmentation. In the nuclei of unfertilized eggs, also, the process of disintegration may be accompanied by the fusion of the chromatic reticulum into rods similar to chromosomes, while the fibres of the nuclear membrane focus on several points external to the membrane as the nuclear cavity diminishes, thus forming a figure resembling a multipolar spindle. Occasionally, before the nucleus begins to diminish in size, the disintegrating chromatin contents are found collected near together, with numerous radiations present in the nuclear cavity, the whole suggesting a possible stage of fertilization.

\section{FERTILIZATION AND THE FIRST SEGMENTATION.}

When the egg-nucleus is reached, the sperm-nucleus flattens itself against it in the form of a bi-convex lens and soon comes to lie within its original boundary (Fig. 37). The surface of separation is at this time quite even and is composed of the two nuclear membranes with some included cytoplasm. The reticulum in the apex of the egg-nucleus is pressed down in advance of the sperm-nucleus and furnishes the first deposit of chromatin at that point.

The difference in the density of the sperm-nucleus and eggnucleus is very apparent when they are thus first in contact, but the former begins almost immediately to lose its density and to become a perfect resting nucleus like that of the egg. In the process, no stainable substance is cast out into the cytoplasm, such as is described by Ikeno (I898) for Cycas, and Wager (1899) for some Phycomycetes; nor can any of its contents be seen to pass through the membranes into the cavity of the egg-nucleus; but increase in the number or in the size of the nucleoli of the sperm-nucleus is very evident (Figs. $4 \mathrm{I}, 42$ ). The deeply staining nucleoli occupy the centre of the nucleus, while its periphery shows a delicate chromatic 
reticulum, which may have been present before, concealed by the dense contents of the nucleus, or may arise only after the contact of the sexual nuclei. Certain granules of this reticulum now gradually become larger by the addition of neighbouring granules, and the whole contracts to a coarse, knotted, slightly anastomosing thread, which, with the assistance of the nucleoli, passes over into the spirem band (Figs. 43-45).

While the sperm-nucleus has thus been entering upon the early stages of division, the chromatin of the egg-nucleus has been collecting near the centre of the nuclear cavity not far from the membranes separating the two nuclei. It likewise presents the appearance of an anastomosing, knotted thread, in contact with granules and spheres of various sizes apparently derived from the nucleoli, which latter now become hollow and stain feebly, and finally disappear.

Changes have also occurred meanwhile where the nuclear membranes are in contact. Instead of the even surface presented at the first contact of the nuclei, the membranes are now separated by numerous spherical granular areas, which tend to encroach on the cavity of the egg-nucleus and cause its membrane to show in cross-section a series of crenate folds. The contents of these spheres stain very slightly, with the exception of one or two small spherical bodies which are precisely like nucleoli and take the nucleolar stains. The disappearance of the membranes and the consequent union of the two nuclear cavities first occurs at points between these granular spheres, and the latter continue to occupy their position until the appearance of the spindle-fibres among them, when all of them disappear except a few upon which the fibres are centred. Whether they have any direct connexion with the formation of the spindle, or are simply cavities between the nuclear membranes containing a small amount of cytoplasm caught between the conjugating nuclei, it is impossible for me to say. Their increase in size with the decrease in density of the sperm-nucleus has suggested to me the arrangement found in Cycas and Cephalotaxus, where fusion is accelerated by root-like projections of the sperm- 
nucleus into the egg-nucleus; but, even if the analogy were otherwise perfect, the increase in the amount of nucleolar substance seems to fully account for all the contents of the sperm-nucleus not found in its chromatic reticulum.

The breaking down of the membranes separating the two nuclear cavities occurs before the completion of the spirem bands, but the chromatin masses remain distinct until the chromatic segments appear. The achromatic contents of the cavity, however, undergo a decided change, becoming denser and more fibrous in appearance with the probable rearrangement of the linin network under the stimulus causing division (Fig. 45). The outer membrane also disappears in places, and some of the cytoplasm presses into the cavity, but the chief activities of division are intranuclear. With the union of the nuclear cavities there also occurs a change in the cytoplasm of the egg. The dense sheath of small granules and fibres that encircles the unfertilized egg-nucleus partly disappears, and the larger cytoplasmic granules extend almost to the nuclear cavity, while the rows of elongated granules, radiating into the surrounding cytoplasm from the egg-nucleus since its origin, now lose their radial position and are distributed without special arrangement. The indications are that the egg-nucleus has relaxed its hold for a time upon its cytoplasm to enter upon the changes involved in division.

The fibres originating the spindle of the first segmentation arise among the segmenting spirems derived from the two nuclei, and they first draw together at several different points forming a multipolar spindle-rudiment. On these fibres the long bent and twisted chromosomes appear, still showing the chromatin disks distinct on the linin thread (Fig. 47). As the number of fibres increase, and the spindle becomes monaxial in form, the chromosomes contract and become homogeneous, and are mostly bent in the form of a $U$. There is no difference to be observed between the chromosomes of the sperm and those of the egg, and, at this stage, they are mingled indiscriminately near the centre of the common spindle. 
The mature spindle is broad, with many fibres and rather blunt ends, and, during the metaphase, the twenty-four chromosomes occupy all of the equatorial plane (Figs. 50, 5I). The type of this division, so far as the chromatin is concerned, is the same as that already described for the central cell of the archegonium. The position of the mature spindle in the nuclear cavity seems independent of the relative position of the conjugating nuclei, and, while the division is usually oblique, it may be perpendicular to, or parallel with, the longitudinal axis of the archegonium (Figs. 52, 54, 57).

The chromosomes pass to the poles as slender undulated V's or U's, and fuse to form the network of the daughternuclei (Figs. 53, 54). No cell-plate is formed, but the fibres fade away into the cytoplasm, the slightly thickened middle portions being the last to disappear.

\section{THE PRO-EMBRYO.}

The two free nuclei resulting from the first segmentation increase rapidly in diameter, and soon divide simultaneously without change of position to form four nuclei of equal size lying free near the centre of the egg (Figs. 54-58). The type of the second division is similar to that of the first, but the spindle is narrower and more pointed at the ends (Fig. 56). The daughter-nuclei are formed and the spindle-fibres absorbed as in the first division. When the four nuclei have attained their full size, they move to the base of the archegonium (Figs. 59, 60), and by successive divisions in a horizontal plane give rise to four tiers of nuclei with four nuclei in each tier, as has been already described for various Conifers.

When the four free nuclei are moving through the eggcytoplasm they do not show any special collections of fibres about their membranes, but soon after the base is reached they become enclosed in a dense mass of fibrous substance (Fig. 60), which supplies the material for the walls that appear later. Above this fibrous mass is a zone showing a delicate reticulum almost devoid of stainable substance. Above this 
zone the egg shows its normal structure. The cause of this hyaline zone is difficult to determine. It appears that the stored food has been taken from this region in order to provide for the growing want of supplies for the nuclei below ; but since the remaining available contents of the egg are doubtless also transferred to the developing embryo, there is no apparent reason why this zone should be left. It possibly represents an intermediate condition of these contents in which they do not easily take or retain stains.

\section{Summary.}

The archegonia of Tsuga originate as single superficial cells, in each of which occurs the usual division cutting off an outer smaller cell that forms the neck. At maturity, the neck most commonly consists of two cells, though in very many cases the neck-cell fails to divide at all. Three and four cells in the neck are less commonly observed.

In the division of the central cell the spindle-fibres arise from a large dense fibrous mass beneath the nucleus and grow into the nuclear cavity, where they are later joined by fibres from the very small upper pole. The division resembles that recently described for many vegetative cells, but belongs to a new and distinct type hitherto undescribed. The mass of cytoplasm at the lower pole with its extensive radiations suggests a huge centrosphere.

As the egg-nucleus increases in size and moves to the centre of the egg, the vacuole moves upward, passing it on its way, and comes to lie near the egg-apex. Just beneath the ventral canal-cell may always be found another somewhat smaller vacuole with contents similar to those of the nucleus. These vacuoles form the receptive spot of the egg.

The contents of the pollen-tube cast into the egg consist of the vegetative nucleus with some cytoplasm and starchgrains, the stalk-nucleus surrounded by its own scanty, vacuolate cytoplasm, and the two unequal sperm-cells with their dense cytoplasm and large deeply-stained nuclei. The larger 
sperm-nucleus slips from the cell and conjugates with the egg-nucleus, the smaller one being gradually absorbed with the other structures derived from the pollen-tube.

The functional sperm-nucleus flattens itself against the egg-nucleus in the form of a bi-convex lens, and the two nuclei soon come to lie in the space formerly occupied by the egg-nucleus alone, their membranes, however, remaining intact for a long time. In this condition the sperm-nucleus rapidly loses its density and constructs a delicate peripheral chromatic reticulum and larger central nucleoli, thus becoming a perfect resting nucleus similar to that of the egg. The chromatin of each nucleus collects in the form of a thick knotted thread near the centre of the separating partition, and the two masses remain distinct until the spirem-bands begin to segment.

Just before the spirems are formed the separating membranes disappear and the nuclear cavities become united. The spindle then arises in a multipolar fashion between and among the two masses, twelve chromosomes being supplied from the chromatin of the sperm and twelve from that of the egg, as described by Blackman for Pinus Sylvestris. The mature spindle is broad with blunt ends, and the manner of division is typical.

A second division succeeds the first without much delay, and the four resulting free nuclei soon attain full size and move to the base of the archegonium, where the young embryo becomes established in the manner already so well known among Conifers.

The investigations leading to the results recorded above were conducted in the Botanical Laboratory of Cornell University under the direction of Professor George F. Atkinson, at whose suggestion this work was undertaken, and for whose kindly sympathy and invaluable aid in its prosecution I am deeply grateful. 


\section{and Fertilization in the Hemlock Spruce. 601}

\section{BIBLIOGRAPHY.}

ANDrews, G. F., '98 : Camera Drawing. Zeitschr. f. wiss. Mikr., xiv, 45 I-452, I 898.

ARnoldi, W., ' $00^{1}$ : Beiträge zur Morphologie der Gymnospermen: iii. Flora, lxxxvii, 46-63, pl. I-2, I900.

' $00^{2}$ : Beiträge zur Morphologie der Gymnospermen: iv. Flora, lxxxvii, I94-204, pl. 6, I900.

Blackman, V. H., '98: On the Cytological Features of Fertilization and Related Phenomena in Pinus Sylvestris, L. Phil. Trains. Roy. Soc., B., cxc, 395-426, pl. I 2-I 4, I 898.

Chamberlain, C. J., '99 : Oögenesis in Pinus Laricio, Poir. Bot. Gaz., xxvii, 268-280, pl. 4-6, I 899 .

Dixon, H. H., '99: The Possible Function of the Nucleolus in Heredity. Ann. Bot., xiii, $269-278$, 1899 .

Fulmer, E. L., '98 : Cell Division in Pine Seedlings. Bot. Gaz., xxvi, 239-246, pl. $23,24,1898$.

Guignard, L., '91: Nouvelles Études sur la Fécondation. Ann. d. sc. nat., Botanique, $7^{\circ}$ sér., t. xiv, I63-396, pl. 9-18, I89I.

Hof, A. C., '98: Histologische Studien an Vegetationspunkten. Bot. Centralbl., lxxvi, Nos. $3-7$, pl. 3-4, I898.

IKENo, S., '98: Untersuchungen über die Entwickelung der Geschlechtsorgane und den Vorgang der Befruchtung bei Cycas revoluta. Jahr. f. wiss. Bot., xxxii, 557-602, pl. 8-10, I898.

Mottrer, D. M., '92: On the Archegonium and Apical Growth of the Stem in Tsuga Canadensis and Pinus Sylvestris. Bot. Gaz., xvii, r 4I-I 43, pl. 8, $189^{2}$.

Nemec, B.,'98: Ueber die Ausbildung der achromatischen Kerntheilungsfigur im vegetativen und Fortpflanzungsgewebe der höheren Pflanzen. Bot. Centralbl., lxxiv, $\mathrm{I}-4,8$ text-figures, 1898.

'991 : Ueber Kern- und Zelltheilung bei Solanum tuberosum. Flora, lxxxvi, 2I 4-227, pl. I3-I4, I 899 .

'99² : Ueber die karyokinetische Kerntheilung in der Wurzelspitze von Allium Cepa. Jahr. f. wiss. Bot., xxxiii, 313-336, pl. 3, I 899.

Rosen, F., '95 : Kerne und Kernkörperchen in meristematischen und sporogenen Geweben. Cohn's Beitr. z. Biol. d. Pflanz., vii, 225-31 2, pl. 2-4, I895.

Strasburger, E., '84 : Neue Untersuchungen über die Befruchtungsvorgänge bei den Phanerogamen als Grundlage für eine Theorie der Zeugung. Jena, I 884 .

'88 : Ueber Kern- und Zelltheilung im Pflanzenreiche, nebst einem Anhang über Befruchtung. Histol. Beitr., i, I 888. '92: Ueber das Verhalten des Pollens und die Befruchtungsvorgänge bei den Gymnospermen. Histol. Beitr., iv, I892.

' $97^{1}$ : Kerntheilung und Befruchtung bei Fucus. Jahr. f. wiss. Bot., $\mathrm{xxx}, 35^{\mathrm{I}-374}$, pl. I $7-\mathrm{I} 8$, I 897 .

1897 . 


\title{
602 Murrill.-The Development of the Archegonium
}

Strasburger, E., '00 : Ueber Reductionstheilung, Spindelbildung, Centrosomen, und Cilienbildner im Pflanzenreich. Jena, I900.

Tном, С., '99 : The Process of Fertilization in Aspidium and Adiantum. Trans. Acad. Sci. St. Louis, ix, 285-314, pl. 36-38, 1899.

Wager, H., '99: The Sexuality of the Fungi. Ann. Bot., xiii, 575-597, I 899.

WALdeyer, W., '88: Ueber Karyokinese und ihre Beziehung zu den Befruchtungsvorgängen. Arch. f. mikr. Anat., xxxii, I-I 22. I4 text-figures. 1888.

\section{EXPLANATION OF FIGURES IN PLATES XXXI AND XXXII.}

\author{
Illustrating Dr. Murrill's paper on Tsuga Canadensis.
}

Most of the figures were first drawn with the aid of a camera lucida from a Zeiss microscope, using compensation ocular $\mathrm{I} 2$ and the $2^{\mathrm{mm}}$ homogeneous objective, and then mechanically reduced to the present scale. For some it was necessary to use a lower magnification in the first instance. In using the camera lucida, I found it convenient to employ dark shades of paper (Andrews, I 898), usually black or dark blue, and the outlines were traced upon it in Chinese white with a long pointed pen. Since most of the preparations are coloured with dark stains, a white medium is peculiarly suitable for outlining chromatic structures.

\section{PLATE XXXI.}

Fig. I. $(x 400$.$) A portion of the apex of the prothallium, showing an arche-$ gonial rudiment in the centre, with rudimentary sheath-cells on each side.

Fig. 2. ( $x$ 400.) The archegonial rudiment has increased in length, and its nucleus is preparing to divide. Almost all the protoplasm is collected at the upper end of the cell. The sheath-cells have increased in number.

Fig. 3. ( $\times$ 400.) The archegonial rudiment has divided into an inner central cell and an outer neck-cell. The outer cell is much smaller than the inner.

Fig. 4. ( $x$ 200.) The neck-cell is in division. The central cell is very much larger, and is being rapidly filled with protoplasm from the rich layer of sheathcells that closely envelop it. Its nucleus remains near the neck-cell and is still in the resting stage, though the condensation of cytoplasm just below it indicates that division is not far off.

Fig. 5. ( $\times$ 400.) A later stage of the same, showing the anaphase of the division in the neck-cell.

Fig. 6. ( $\times$ 400.) A still later stage, showing the neck-cell divided into two cells. The central cell is now entering upon division.

Fig. 7. $(\times 200$.$) A mature archegonium, with two cells in the neck. The$ division wall is oblique. The ventral canal-cell is also shown. 


\section{and Fertilization in the Hemlock Spruce. 603}

Fig. 8. ( $\times$ 200.) A mature archegonium, with three cells in the neck. The first division was transverse, and the upper cell afterwards divided longitudinally.

Fig. 9. $(\times 200$.$) Four neck-cells are present, formed by one longitudinal$ division followed by two oblique ones. The cytoplasm of both cells has divided, but no separating walls could be observed.

Fig. Io. ( $x$ 200.) In this archegonium the four neck-cells are in one row, formed by two successive transverse divisions. Beneath the neck is the disorganizing ventral canal-cell, and beneath the ventral canal-cell, at the apex of the egg, is the nuclear vacuole. The empty vacuole is in another section. At the centre of the egg is the large resting nucleus. About the periphery of the egg, proteid vacuoles are abundant. The larger granules of cytoplasm are arranged in rows radiating from the nucleus. The contents of the egg have become so dense that its reticulum is wellnigh concealed. In many places, also, the reticulum has been distorted by denser aggregations of nutritive materials.

Fig. II. ( $x$ 200.) This follows Fig. 3 in the order of development, but shows a marked increase in the size of the central cell, with a well-formed sheath. The nucleus is at the apex of the cell, where it remains until division. Throughout the cell-cavity a delicate reticulum has been constructed, which is interrupted at the centre of the cell by a large vacuole filled with sap.

Fig. I 2. ( $x$ 200.) A later stage in the development of the archegonium. The neck-cell has elongated. The central cell has enlarged, and the meshes of its reticulum are fast filling with granular food supplies. The first proteid ${ }^{\text {vacuoles }}$ have been formed.

Fig. I3. ( $x$ 400.) This figure represents the nuclews of the central cell preparing to divide. Its reticulum has become coarser and stains more deeply, and is balled up in the centre of the nuclear cavity in a condition suggesting synapsis. The preparations showing this condition are fixed as perfectly as one could desire. Beneath the nucleus is a dense fibrous mass closely pressed against the nuclear membrane, and sending out radiating fibres into the cytoplasm.

Fig. 14. $(x$ 800. $)$ The spindle-fibres are arising in this mass, and growing upward against the membrane.

Fig. 15. ( $x$ 800.) A lenticular hyaline area at the upper pole, seen in only two or three preparations, but very distinct and apparently perfectly normal.

Fig. 16. ( $x$ I 50.) A cross-section of a prothallium containing five archegonia of the stage shown in Fig. I2. It will be observed that each archegonium is enveloped by its own one-layered sheath. The archegonia are, therefore, ordinarily separated by two rows of sheath-cells, but at points where there is some distance between the archegonia the cells of the two sheaths have divided to fill the space. Between the two upper archegonia in the figure, the sheaths have been crushed to a line. This is quite frequently the case where the curved surfaces of the archegonia come nearest together.

Fig. I7. $\left(x\right.$ 800.) Following Fig. I $_{4}$, and showing the pressing in of the nuclear membrane, in the form of blunt protuberances, by the spindle-fibres originating below. The chromatin thread is now peripheral and almost continuous, though the disks are still far apart.

Fig. 18. ( $\times 800$.$) The spindle-fibres have advanced still farther, and pre-$ parations are being made within the nuclear cavity for their continuation. Segmentation occurs about this time, and rows of granules and delicate threads connect the chromatic segments with the incoming spindle-fibres. The greater 


\section{Murrill.-The Development of the Archegonium}

part of the chromatin is in the upper half of the nucleus. Activity has now begun at the upper pole, where delicate fibres are seen growing down against the nuclear membrane, but it rarely appears so distinct as in this preparation.

Fig. 19. $(x 800$.) This nucleus belongs to a larger archegonium than that shown in Fig. I8. The spindle is in about the same stage, but the chromosomes are more advanced than those shown in the preceding figure. Radiations are present at the upper pole, and possibly a small polar cap, but the latter, if present, is not distinct enough to figure.

Fig. 20. ( $\times 800$. $)$ This figure represents the same stage as Fig. 19, but the nucleus remains spherical, and the spindle-fibres seem to have originated at a greater distance than usual below the nuclear membrane, and to have advanced with a more even front. This is exceptional, being observed only a few times in the examination of a large number of preparations.

Fig. 2I. $(x 800$. $)$ The nuclear membrane has disappeared opposite the poles, and the spreading cone-shaped bundles of spindle-fibres have grown into the nuclear cavity, and are uniting somewhat above the centre of the nucleus. The true pear-shaped form of the nucleus and the inequality of the two poles cannot be shown in a longitudinal section which includes the upper pole, since the division is oblique and much of the lower pole is cut away. When first formed, the spindle is broad and the chromosomes, which have now become homogeneous, are attached to its outer threads.

Fig. 22. ( $x$ 800.) The spindle-fibres are now homogeneous throughout, and the spindle has narrowed and drawn in the completed chromosomes nearer to the centre. In narrowing, it has also elongated, and the upper pole has been elevated. The section is made as in Fig. $2 \mathrm{I}$, and does not show all of the lower pole.

Fig. 23. ( $\times 800$.$) Further narrowing of the spindle has taken place, and the$ chromosomes are now coming up to the equator, preparing to enter the plate stage. The equatorial portion of the nucleus approaches very near the wall of the egg, and above this line the small cap of cytoplasm is dense and full of fibres.

Fig. 24. $(\times 400$. $)$ The lower pole of the mature spindle is here represented. The fibres come to a definite point, and, in this case, focus on a small hyaline granule, which shows none of the properties of a centrosome.

Fig. 25. ( $\times$ 400.) The fibres of the mature spindle also converge to a definite, though rather abrupt, point at the upper pole, from which supporting fibres extend to the cell-wall. The remainder of the nuclear membrane also appears to function as a support to the spindle during metakinesis.

Fig. 26. ( $\times 800$.) Separation of the chromosomes has begun at the nuclear plate, the bundles of mantle-fibres being attached on opposite sides of the diamondshaped openings in the chromosomes already seen in earlier stages.

Figs. $27,28 .(\times 600$.) The daughter-chromosomes pass to the poles as U's or V's with undulated margins. After they reach the poles, the central spindle-fibres appear lax, and the spindle becomes slightly concave in the equatorial region. This may be due to artificial causes or to relaxation after removal of the strain.

Fig. 29. ( $\times$ 400.) The daughter-chromosomes have united into a close, deeplystaining spirem, but no membrane is yet formed about them. The inner spindlefibres are beginning to thicken in the equatorial region preparatory to the formation of the cell-plate.

Fig. 30. $(\times 400$.$) The dispirems have opened out, but their loops still$ maintain a position parallel with the axis of the spindle. Delicate nuclear mem- 


\section{and Fertilization in the Hemlock Spruce. 605}

branes have been deposited about the daughter-nuclei, while the last traces of the membrane of the mother-nucleus have disappeared. The large dense mass of cytoplasm at the lower pole, however, still remains, and is present even when the egg-nucleus begins to pass down. The formation of the cell-plate is proceeding pari passu with the increase in diameter of the daughter-nuclei.

Fig. 3I. $(\times 400$.$) The daughter-nuclei have reached the resting stage, and$ show a delicate reticulum with several nucleoli. The egg-nucleus is somewhat larger than that of the ventral canal-cell. The cell-plate has been continued to the wall of the mother-cell.

Fig. 32. ( $\times$ 400.) The egg-nucleus is now not only larger than the ventral canal-cell nucleus, but its reticulum is growing more rapidly. The chromatic contents of the nucleus are mostly confined to its upper portion, the lower part containing chiefly nuclear sap.

Fig. 33. $(x 400$.$) The reticulum of the egg-nucleus has become coarser$ and the nucleoli larger. The nucleus has also changed its form from spherical to ellipsoidal, and has begun to move through the dense polar cytoplasm toward the centre of the egg. The larger granules of the general cytoplasm are arranged in radial rows about the nucleus, and the granules themselves are radially elongated.

Fig. 34. ( $x{ }^{250}$. $)$ At this stage the reticulum of the egg nucleus is distributed throughout the entire nuclear cavity. As the archegonium is unusually broad, the nucleus has retained its spherical form. Passing it on the left is the large central vacuole which now takes a position near the egg apex. The nucleus of the ventral canal cell is irregular in outline, and its contents show signs of disorganization. Traces of the division-spindle still remain above the nucleus.

\section{PLATE XXXII.}

Fig. 35. ( $\times$ 300.) The nucleus here represented is drawn from an egg into which the contents of the pollen-tube have just been discharged. Situated near the base of the nucleus, is the very large nucleolus with its firm, deeply staining outer shell broken at one point. The contents of the nucleolus appear finely granular and vacuolate in stained preparations.

Fig. 36. ( $x$ 200.) The contents of the pollen-tube have entered the egg near its apex on the right hand side in the figure, and now lie beneath the empty vacuole with the functional sperm-nucleus in advance, and already free from its cytoplasm. Near it on the left is the stalk-cell, while between it and the spermcell lies the vegetative nucleus. The contents of the first sperm-nucleus are very dense and stain deeply. The egg-nucleus is apparently unaffected by the near approach of the sperm. Just above the egg are the remains of the neck-cells and the ventral canal-cell pushed aside by the entering pollen-tube.

Fig. 37. $(x$ 200. $)$ The first sperm-nucleus has flattened itself against the apex of the egg-nucleus in the form of a biconvex lens. Its contents have as yet undergone no change. The second sperm-nucleus remains in its cytoplasm above, showing its reticulum and nucleoli very distinctly. The smaller nuclei are in another section. The first sperm-nucleus has left slight traces of its passage to the egg-nucleus in the intervening cytoplasm. These traces are more distinct in Fig. 38 .

Fig. 38. ( $x$ 200.) The sperm-nucleus has lost its density, and is now a true 


\section{Murrill. - The Development of the Archegonium}

resting nucleus like that of the egg. The membranes of the two nuclei are still intact. The changes in the two nuclei may be better described under later figures. In this case the stalk-cell lies near the second sperm-nucleus.

Fig. 39. ( $x$ I 600: $)$ The stalk-cell enlarged from the section represented in Fig. 38 to show its thick nuclear reticulum, and scanty vacuolate cytoplasm.

Fig. 40. ( $x$ 200.) This figure shows the first sperm-nucleus in contact with the egg-nucleus, and the second sperm-nucleus almost touching its membrane. The sperm-cells entered the egg unusually far down on its side, and the bursting of the pollen-tube was sufficient to force them to this position near the egg-nucleus. This also accounts for the contact of the first sperm-nucleus at the side instead of the apex. The remains of the neck-cells could not be found. The eggmembrane did not close up again after the contents of the pollen-tube entered, as was the case in the egg represented in Fig. 36.

Fig. 4I. $(\times 400$.$) This represents a stage succeeding that shown in Fig. 37.$ The contents of the sperm-nucleus are losing their density, and numerous small spheres have appeared in the nuclear cavity. Crenate folds are observed in the membrane of the egg-nucleus at the surface of contact of the two nuclei.

Fig. 42. $(x$ 400. $)$ The dense contents of the sperm-nucleus have disappeared except at the centre, and the nucleoli are larger and fewer in number. About the periphery of the sperm-nucleus a chromatic reticulum is seen. The chromatic contents of the egg-nucleus have begun to migrate to a point beneath the spermnucleus.

Fig. 43. $(\times 400$.$) The centre of the sperm-nucleus is quite free from chromatic$ contents. The peripheral reticulum shows larger collections of chromatin. Nearly all of the chromatin of the egg-nucleus has collected beneath the spermnucleus. The crenate folds in the nuclear membrane of the egg appear larger, particularly in the centre.

Fig. 44. ( $x$ 400.) The chromatin of the sperm seems to have moved nearer to that of the egg. The intervening membranes are preparing to break up. The egg-nucleus has constructed a chromatic reticulum.

Fig. 45. ( $\times$ 400.) The membranes have broken up, and the two nuclear cavities are continuous. Small spheres with granular contents now occupy the position formerly occupied by the membranes. The thick knotted chromatic threads of the two nuclei still remain distinct. All traces of nucleoli have disappeared, and the contents of the nuclear cavity have become denser and more fibrous. At a few points, the outer nuclear membrane is disappearing, and the cytoplasm is encroaching on the nuclear cavity.

Fig. $46 . \quad(\times 800$.$) A tri-polar spindle found near the apex of the egg in the$ position commonly occupied by the second sperm-nucleus.

Fig. 47. $(x$ 800.) Following Fig. 45, and showing the origin of the first segmentation-spindle, which arises between and among the two groups of chromatin. The spirems have mostly segmented at this stage, but the segments have not yet become homogeneous. The chromatin of the egg does not all appear in this section. A preparation showing the two groups of chromosomes to better advantage was injured so that it could not be satisfactorily figured. The spindle is at first multipolar, but soon becomes monaxial, the position of the poles apparently being determined by collections of a dense granular substance which takes a diffuse reddish stain with the Flemming combination. The contents of the 


\section{and Fertilization in the Hemlock Spruce. 607}

nucleus are more fibrous than before, and the nuclear membrane has disappeared, though the limit of the nuclear cavity remains the same.

Fig. 48. ( $\times 800$.) The spindle is now monaxial though not yet distinctly bipolar. The chromosomes are homogeneous, and no longer separated into two groups. The contents of the cavity remain as shown in Fig. 47.

Fig. 49. ( $\times 800$.) This figure apparently represents a later stage than that shown in Fig. 48, but no trace of a spindle could be found, even in very deeply stained preparations. It must either be considered as a cross-section in which the spindle fibres are, for some reason, not easily observed, or the spindle is unusually late in forming.

Fig. 50. $(\times 800$.$) The spindle of the first segmentation at metakinesis. The$ division is typical. No centrosomes are present.

Fig. $5^{\text {I. }}(\times 800$.$) Showing a cross-section of the same.$

Fig. 52. ( $\times 200$.) Same as represented in Fig. 50, but showing a section through the entire egg. The division is here oblique, while in Fig. 56 it is represented as longitudinal, and in Fig. 57 as transverse to the axis of the archegonium.

Fig. 53. $(\times 800$.$) The daughter-chromosomes of the first segmentation ap-$ proaching the poles in the form of U's and V's. By counting them in several preparations at this stage, their number was found to be twenty-four. The fibres of the central spindle appear twisted and somewhat thickened at the equator, but they soon disappear without the formation of a cell-plate.

Fig. 54. ( $\times$ 100.) The young daughter-nuclei resulting from the first segmentation.

Fig. 55. ( $\times$ I00.) The same at an older stage with the chromatin in the resting condition. The cytoplasm between the nuclei is finely granular. Note the remains of the ventral canal-cell at the apex of the egg.

Fig. 56. ( $\times 800$.) A spindle of the second segmentation at metakinesis. It is narrower and more pointed than the first segmentation spindle. The chromatin divides in the same manner, and there are no centrosomes present.

Fig. 57. $(x$ 200. $)$ A fertilized egg containing two nuclei in simultaneous division. The stage of division is the same as that shown in Fig. $5^{6}$.

Fig. 58. ( $\times$ 100.) The second segmentation is complete, and the four resulting nuclei are equal in size and without separating walls.

Fig. 59. ( $x$ 100.) The four nuclei are moving to the base of the archegonium. Their chromatic contents are delicate and scanty. There is no special collection of fibres about the nuclei. The archegonium is cut obliquely so that the position and size of the nuclei are not truly represented in the figure.

Fig. 60. ( $x$ 100.) The four nuclei have reached the base and are arranged horizontally in one plane. A dense fibrous substance surrounds them. Some distance above the plane of the nuclei is a zone showing a regular reticulum quite free from staining contents. Above this zone the normal contents of the egg are observed de eply stained. 


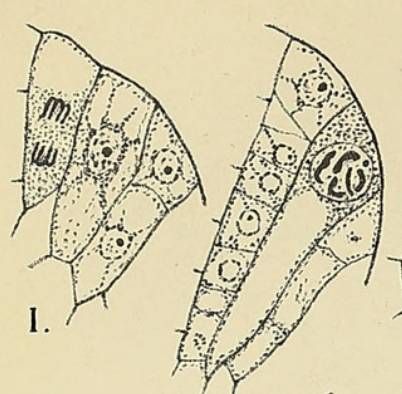

2.

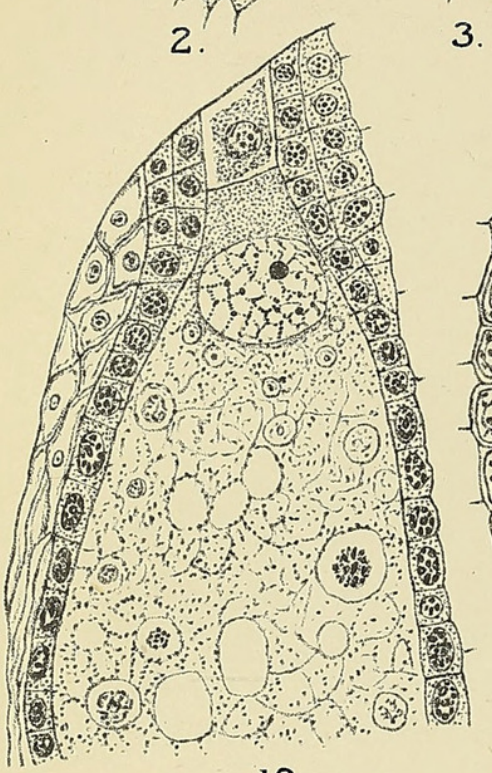

12.

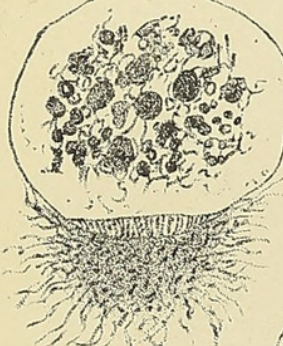

14
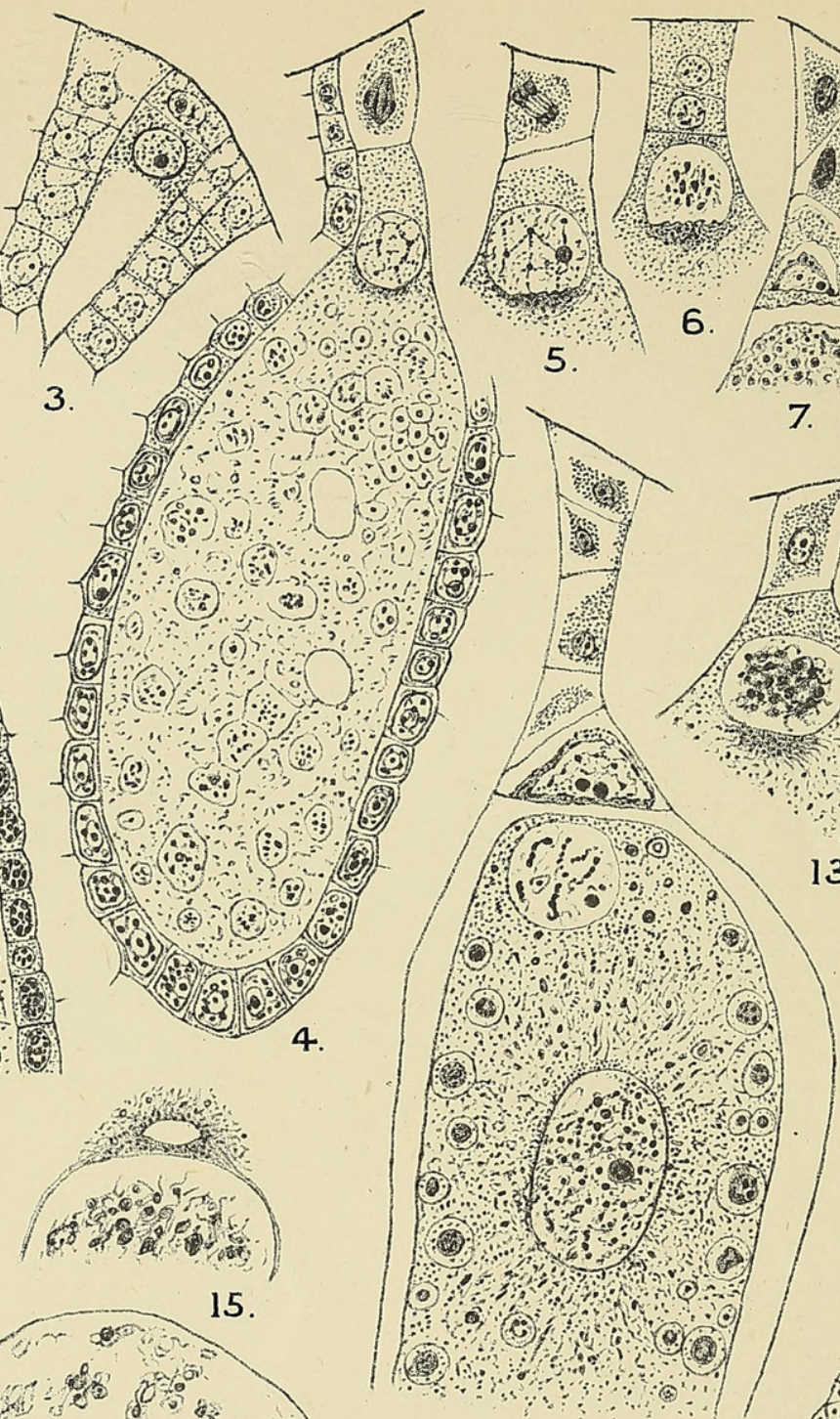

10.

3.

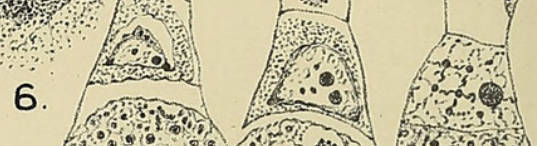

5.
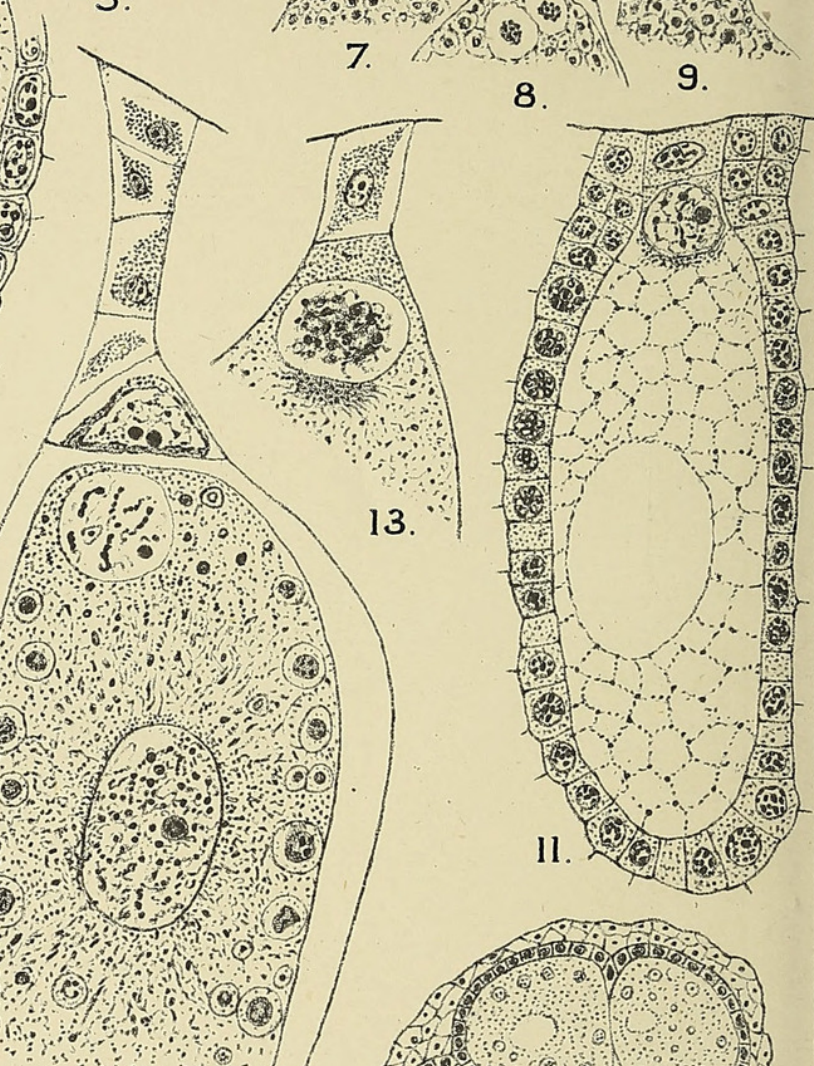

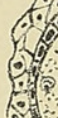

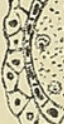

(1) 50 o

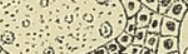

vistiong
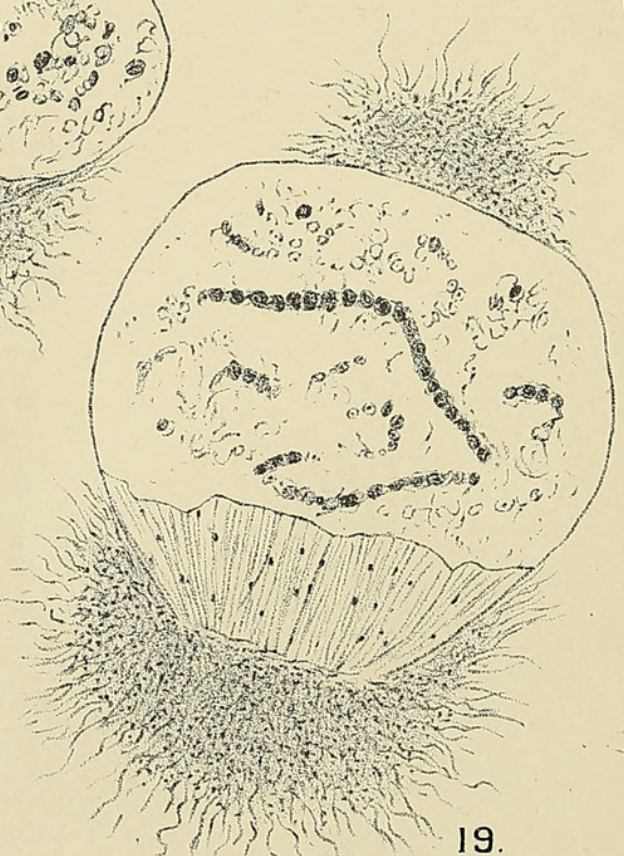

17.

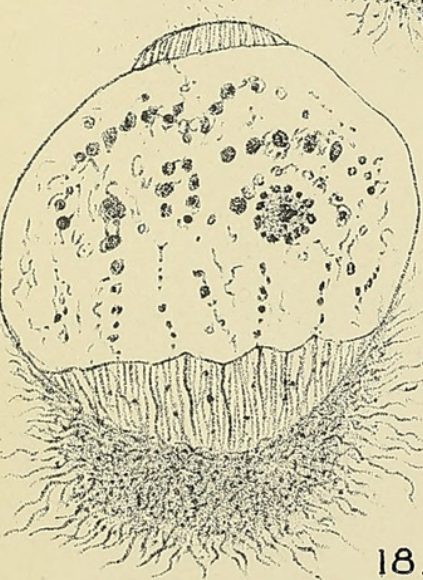


Vol. XIV, PL.XXXI.
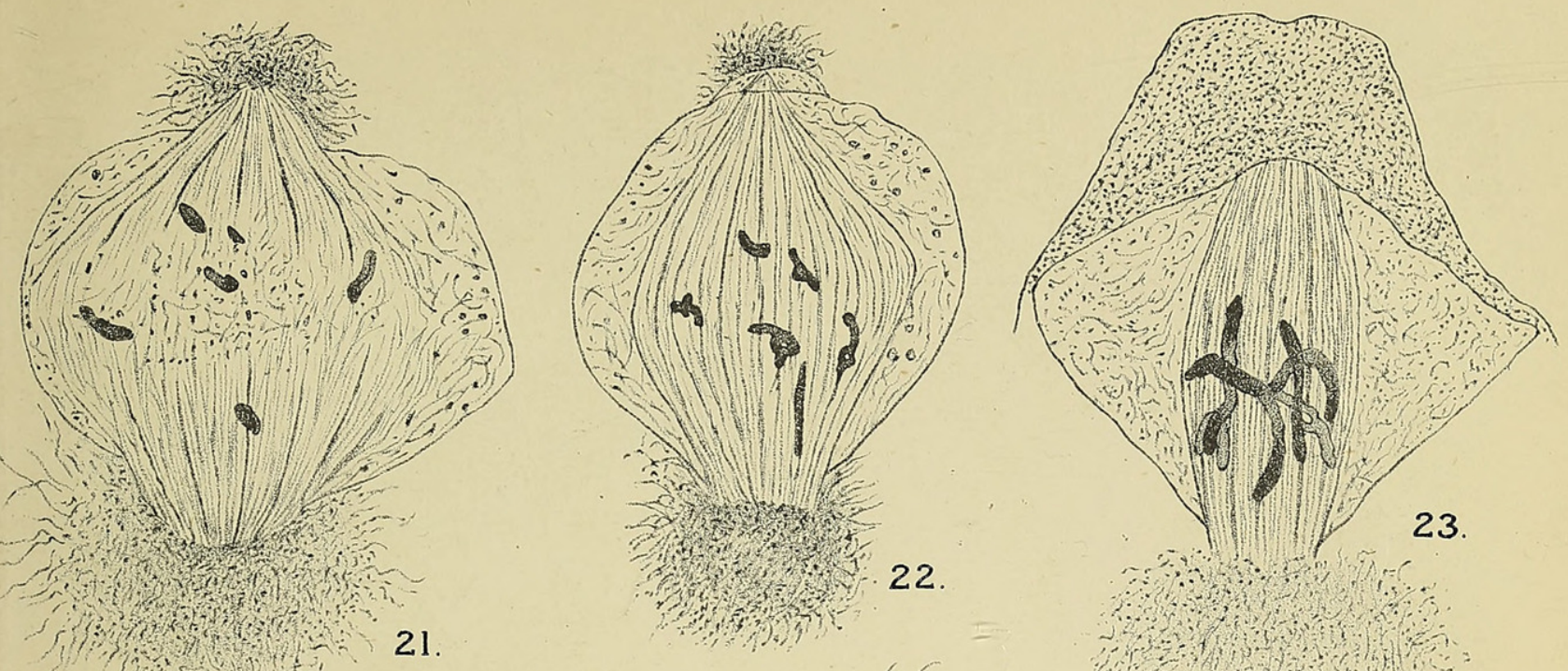

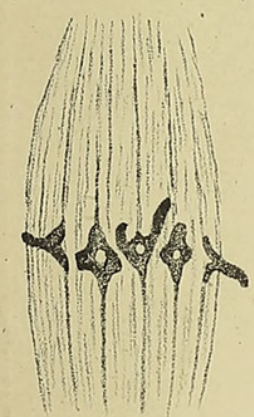

26.

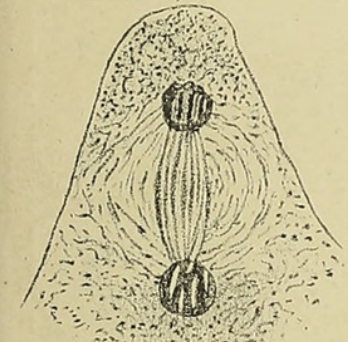

29.

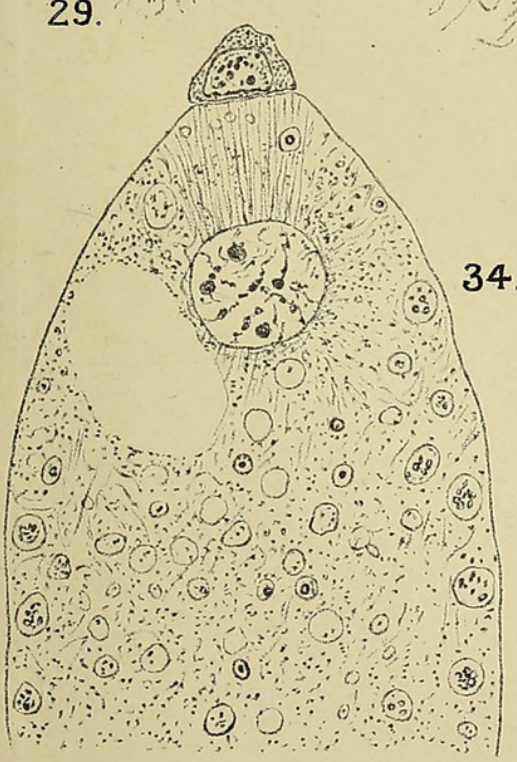

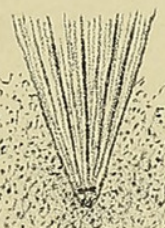

24
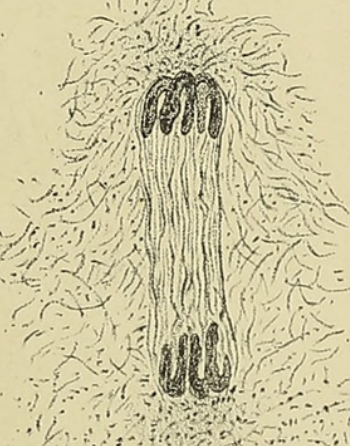

28.
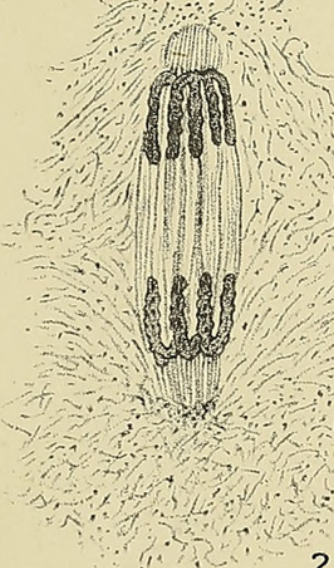

30.
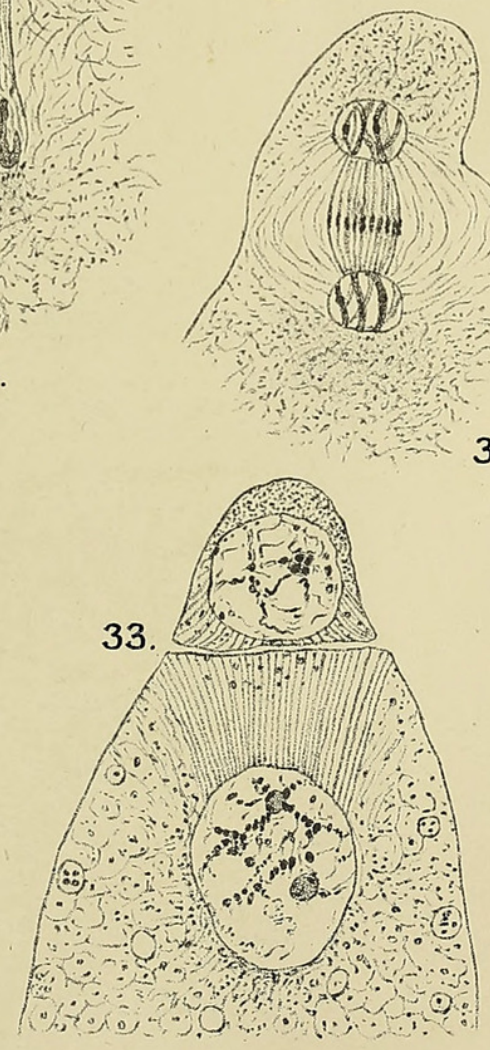

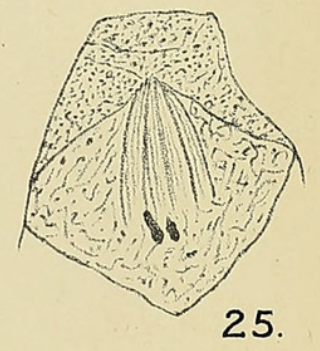

27.

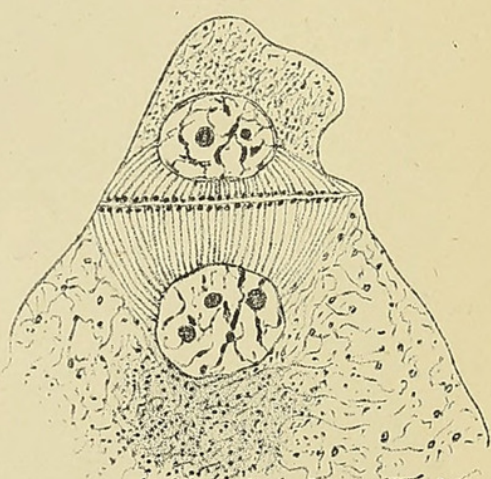

31.

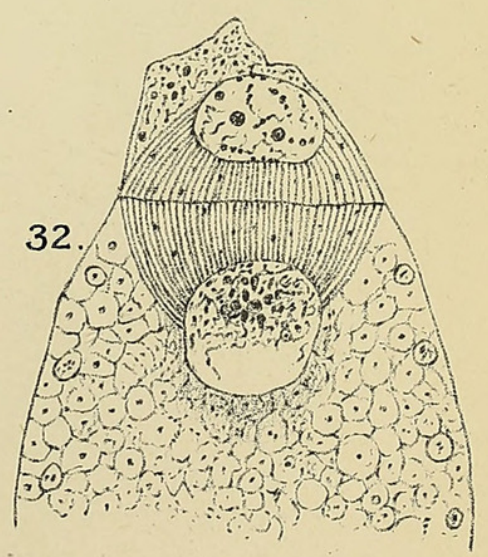

University Press, Oxford. 

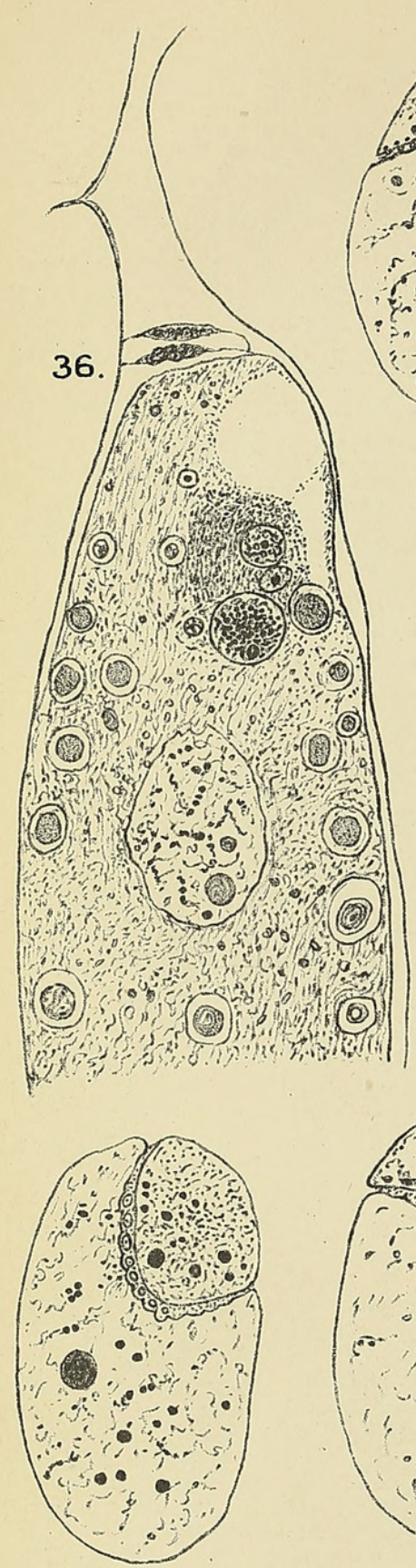

41.

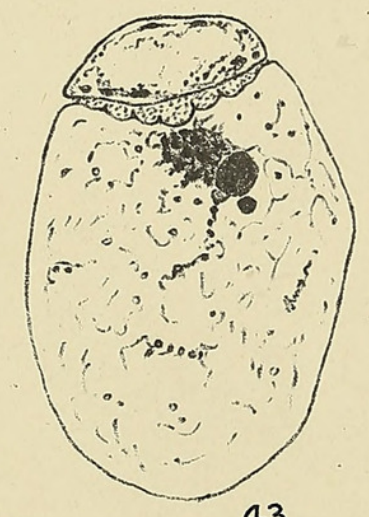

43.
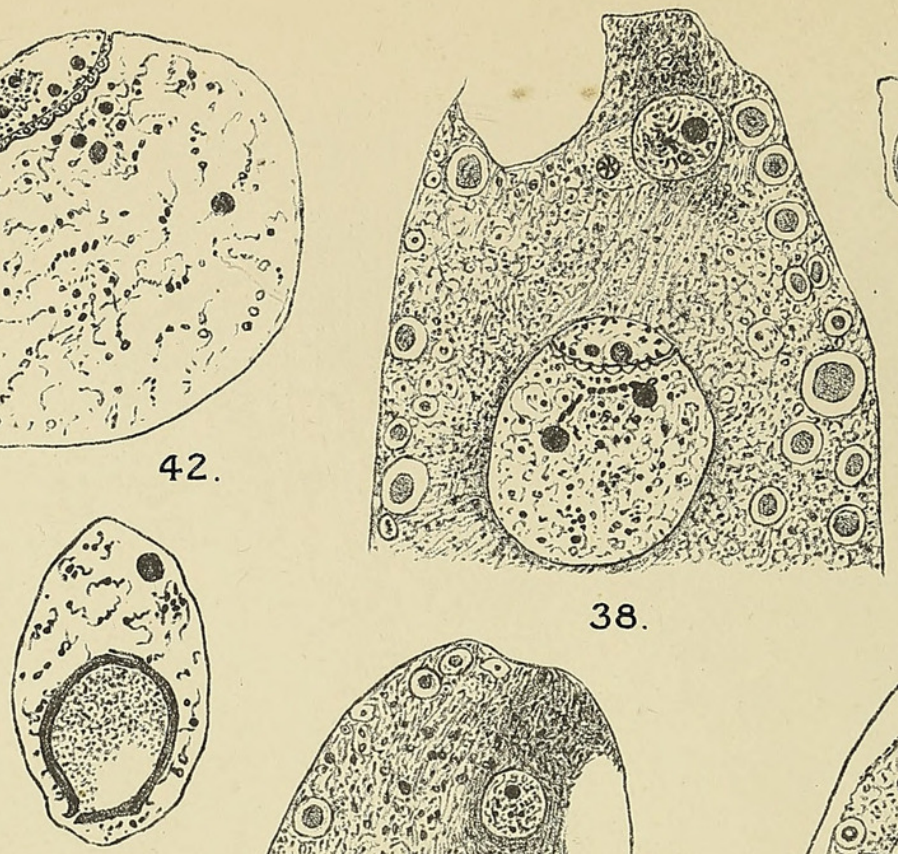

35 .

42

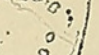

38.

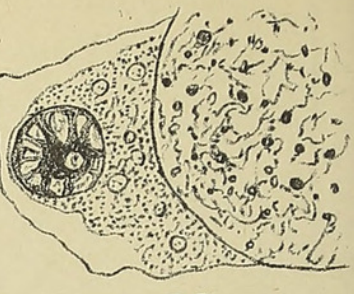

39.

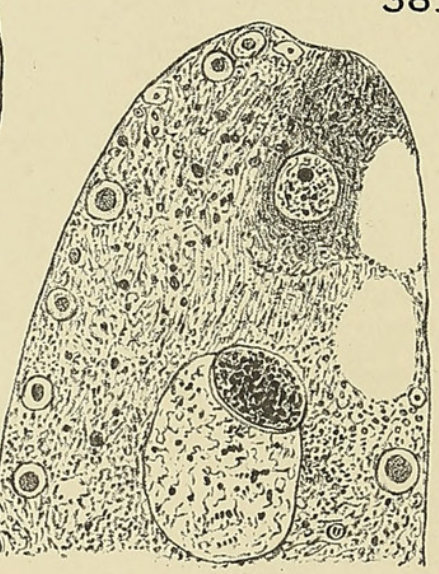

37.

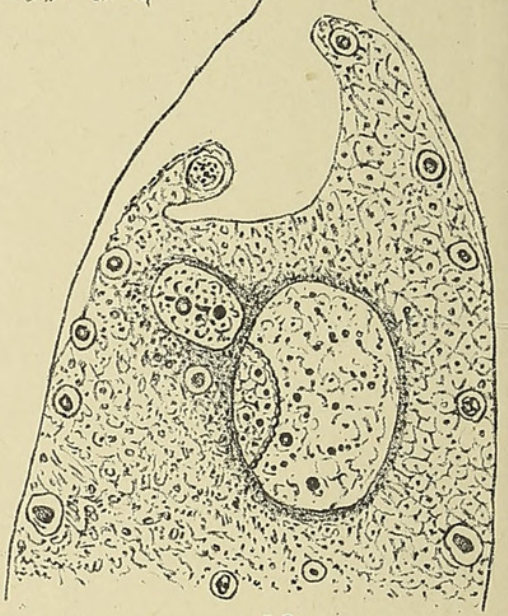

40.
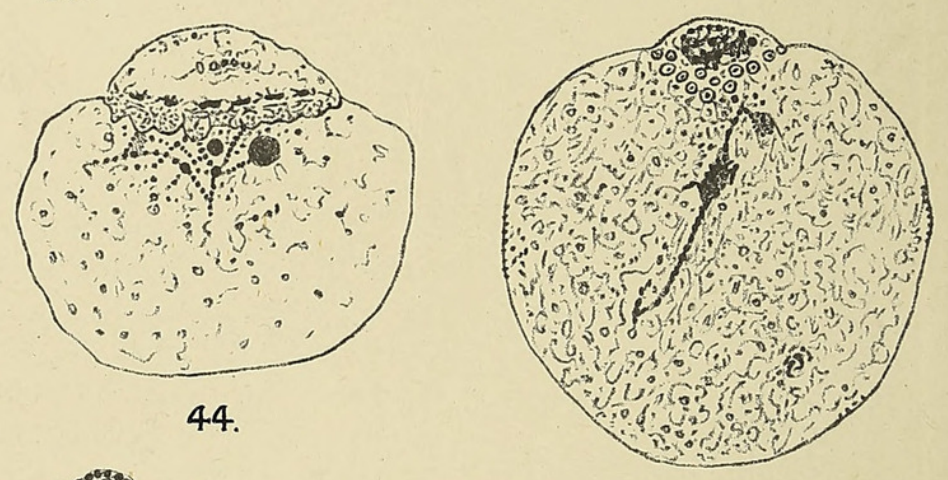

45.
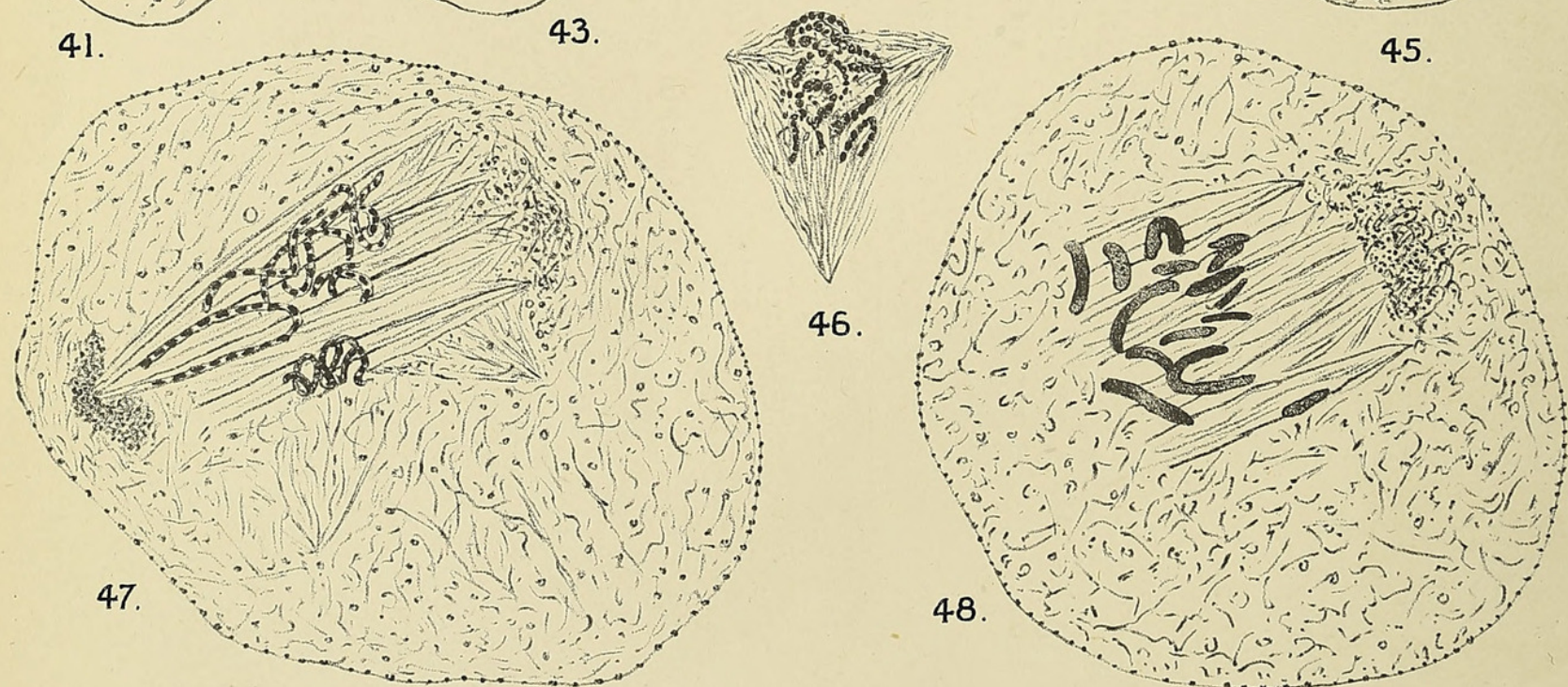

W.A.Murrill, del 


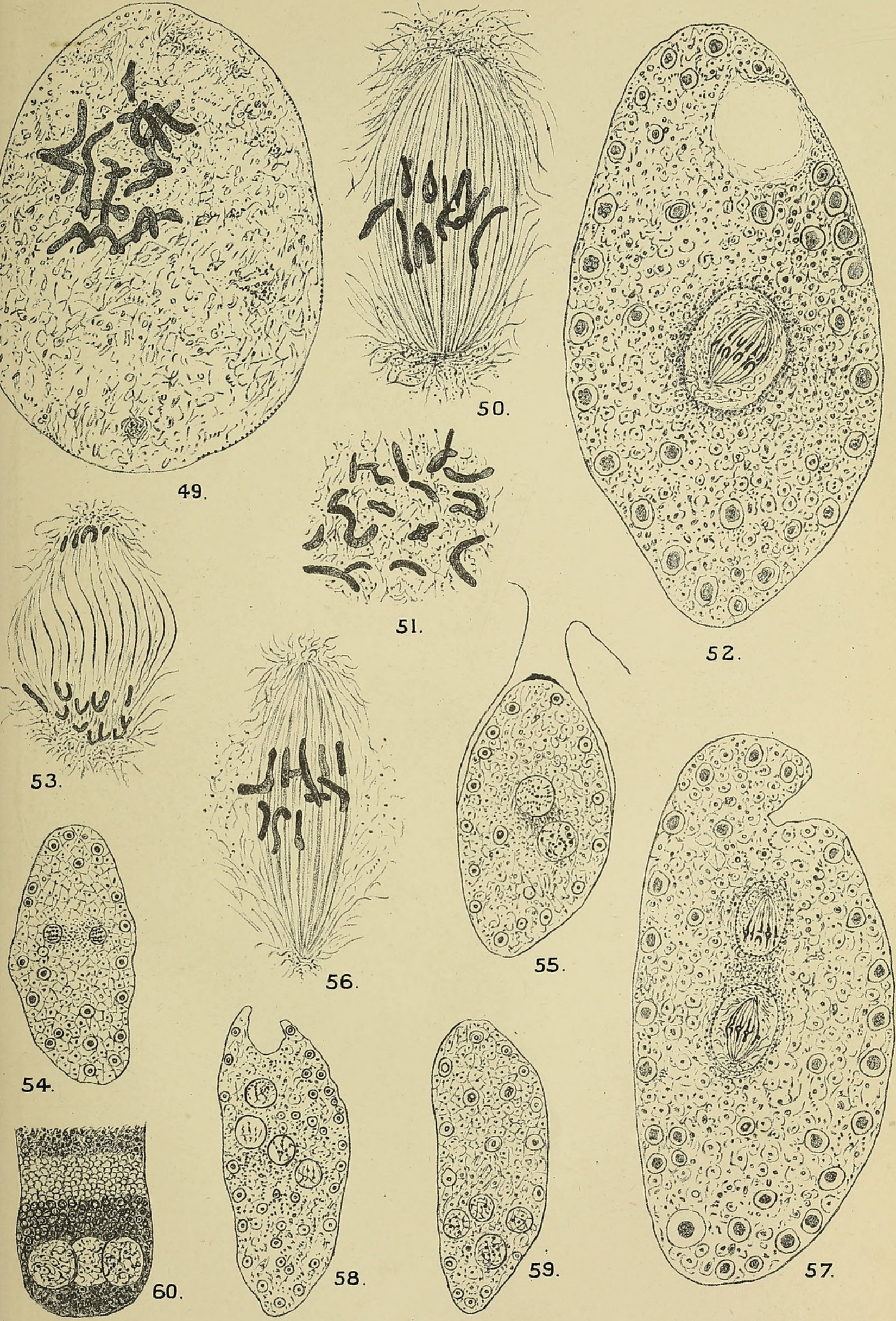

University Press, Oxford. 


\section{$2 \mathrm{BHL}$ Biodiversity Heritage Library}

Murrill, William A. 1900. "The development of the Archegonium and fertilization in the hemlock spruce (Tsuga canadensis, Carr.)." Annals of botany 14, 583-607. https://doi.org/10.1093/oxfordjournals.aob.a088793.

View This Item Online: https://www.biodiversitylibrary.org/item/238259

DOI: https://doi.org/10.1093/oxfordjournals.aob.a088793

Permalink: $\underline{\text { https://www.biodiversitylibrary.org/partpdf/318600 }}$

\section{Holding Institution}

Smithsonian Libraries

\section{Sponsored by}

Biodiversity Heritage Library

\section{Copyright \& Reuse}

Copyright Status: Not in copyright. The BHL knows of no copyright restrictions on this item.

This document was created from content at the Biodiversity Heritage Library, the world's largest open access digital library for biodiversity literature and archives. Visit BHL at https://www.biodiversitylibrary.org. 